\title{
ART CONSUMPTION DURING COVID-19 PANDEMIC: INFLUENCE UPON THE SENTIMENT OF LIFE FULFILMENT
}

\author{
Iuliana Coman \\ Bucharest University of Economic Studies, Bucharest, Romania \\ luliana.Coman.ARDS@gmail.com
}

\begin{abstract}
Art has been present in our life since the beginning of the humanity, participating to the evolution of society and at the same time reflecting the different stages of human evolution.

The aim of this paper is to offer a short analysis regarding the art consumption during the Covid-19 crisis presenting several convictions, perceptions and influences which are manifesting in the art consumers behavior. The research analyzed the influences of art upon the feeling of life fulfilment and upon convictions regarding the capacity of art to influence the life of society.

The analysis is performed using data obtained from an experimental survey on a sample of 200 persons with higher education in the south of Romania. Data were analyzed using SPSS and Microsoft Excel and contain descriptive tables. The analysis took into consideration the comparisons of the results obtained using different statistical methods.

Following the analysis, it was concluded that the consumption of art continued during Covid-19 crisis, the frequency of art consume were rather high due to the availability of various Internet platforms: $75 \%$ of respondents consume at least weekly movies on Internet platforms like Netflix or $\mathrm{HboGo} ; 34 \%$ of respondents consume weekly theater on Internet platforms (online TV stations, plays broadcast online, others); $73 \%$ of respondents consume at least weekly music on Internet platforms (online TV stations, music broadcast online, others). Another conclusion of the research is that the presence of art manifests influences upon the sentiment of life fulfilment and upon the convictions regarding the capacity of art to participate to the consolidation of society.
\end{abstract}

Keywords: Art Consumption, Art influence upon life fulfilment, Art influence upon society

\section{INTRODUCTION}

The beginnings of art are as mysterious as those of language. If we admit that art consists in building temples and houses, in making paintings and sculptures or weaving for an ornamental motif, there are no people who have not developed a form of art. Instead, if we consider art a kind of splendid luxury, intended for museums and exhibitions or the decoration of a gala room, we must realize that the use of the word is as recent as possible and that many of the greatest architects, painters and sculptors of the past never thought about it (Gombrich, 2012). 
The presence of art in the life of each of us as an individual and in the life of society has been and will probably always be a natural need. The hypothesis used in the development of this study is the major influence that art has on society, building, beyond the cultural identity that decisively defines a community, the necessary framework that ensures the progress both at the individual level and at the society level.

Starting from this hypothesis the research evaluates the influence of art on the social context and on individuals. The analysis aims both to obtain an image of the influences of art and to identify some of the dynamics that are manifesting in the market and in the society.

This paper analyses the consumption of art during the restrictions imposed by Covid-19, as well as the influences manifested by the presence of art upon the life of the respondents or on the community. The research includes analyses of the answers received in interviews about the convictions regarding the influence of art on the lives of respondents, and offers also an analysis of the associations between the presence of art in the life of respondents, the sentiment of life fulfilment and different beliefs regarding the capacity of art to influence the life of individuals and of society.

\section{LITERATURE REVIEW}

The influence of art upon the life of individuals and upon the life of society was the subject of several books or studies published starting with the beginning of last century and up to nowadays.

Gabeaud (1930) considers that the origin of music is lost in the night of time, but, according to the memories of men and the oldest traditions, the art of music manifests itself in two particular forms, each corresponding to a very human state of mind: 1 the art of gesture or dance, which expresses joy; 2 the art of sung speech, from contemplation and prayer.

Gombrich (2012) remembers us that in the past the attitude towards painting and sculpture was often the same. They were considered not so much a work of art as objects created for a specific purpose. Among these primitives, construction and imagery come from the same spirit of utility.

The capacity of art to influence the life of individuals and of society was analysed by Muhammad et al. (2016), demonstrating the influence of art upon society. Otte (2019) analyses the capacity of art to participate to the social cohesion. Jeon et al. (2019) describe the utility of art starting with the beginning of human history. De Arriba et al. (2019) underline the capability of art to highlight the problems of our times and to react to them, helping therefore to find innovative solutions to answer these problems. Pantano (2011) published her research revealing the influence of culture on the behaviour of consumers of local products in the Calabria area. The results of the study show the major influence which culture has on consumers' behaviour. Bachled and Bennani (2016) describe the impact of the psychological components on the visual arts, and the results show that the most powerful influences on the behaviour of visual art 
consumers are manifested by several traits of personality. Rodner et al. (2011) present how art has already been defined as an economic agent that participates in the evolution of the economic environment. Croitoru and Becut Marinescu (2017), present the tendency manifested at international level to evaluate the impact of art in the social and economic environment. Studies organized in France or Canada, demonstrate that art has a strong influence in society, developing the independence of individuals, expanding the capacity of knowledge, developing the understanding and the ability to act. Also, art participates in building social cohesion and developing society by encouraging civic participation.

The role of the mass-media in dissemination of information, and the objectivity of the communication in the periods of normalcy or in times of crisis, is analysed by Korstanje and Babu (2016). The research shows how the media plays a dominant role in building the reality they convey to readers. Such a reality reflects the media's own prejudices and those of the interests that control the media.

The Internet has meanwhile become one of the most powerful sources of information. According to https://www.internetworldstats.com/stats.htm there are over 4.5 billion internet users worldwide, and Internet penetration in March 2020 reached values of over 94\% in North America, 87\% in Europe and over $53 \%$ in Asia.

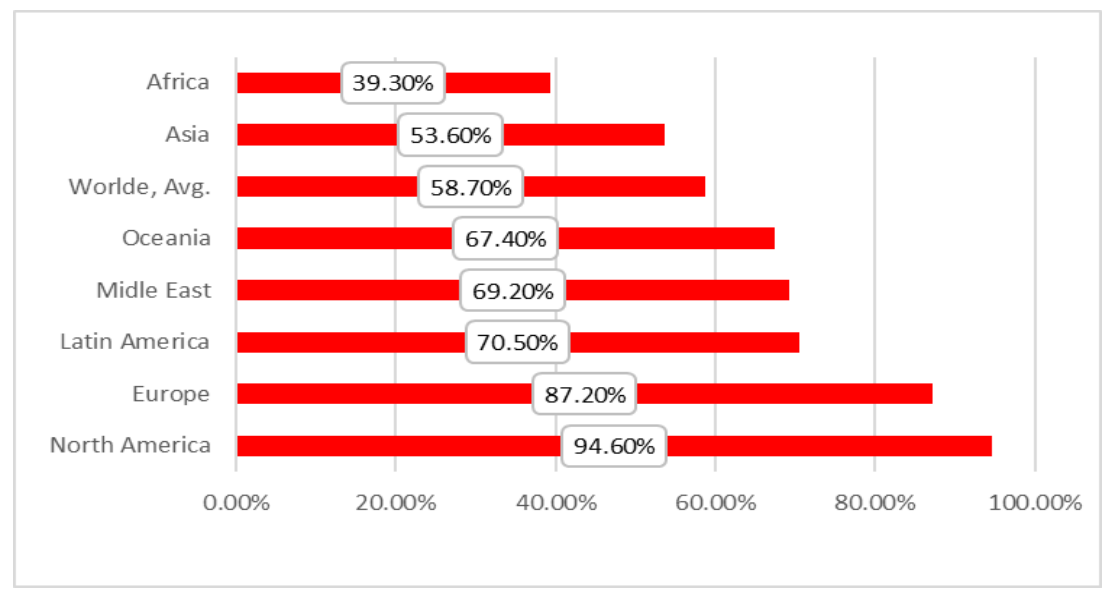

\section{GRAPHIC 1. INTERNET WORLD PENETRATION RATES BY GEOGRAPHIC REGIONS IN JAN - MARCH 2020}

Source: adapted from Internet World Stats - www.internetworldstats.com/stats.htm

The evolution of the Internet, the increasing number of users, the popularity of the Internet generated that context where the information flows are created by interconnected people. Li et al. (2019) show how the processes of disseminating different information are not independent and interact with each other. Modelling and analysing the interactions between related information plays an important role in understanding the characteristics of the information dissemination and a better control of the information 
flows. Chung and Yun (2013) analyse another important aspect that must be considered in communication during the crisis, namely the role of the media in amplifying risk and in politicizing the risk issue. But beyond the increased role in communication that the Internet is gaining more and more, lately the Internet has become the most important solution for access to the different forms of art. In the period preceding the Covid-19 crisis, art was present in our daily lives at almost every step in at least one of the classic forms of manifestation of art: cinema, theatre, music, visual arts (Coman and Mihăiță, 2019). Nissley (2010) also shows that art was present in our lives in a multitude of other forms defined in contemporary society, such as decoration - artwork in hallways / corridors and images on office walls (e.g. Art corporate); entertainment - bringing arts / shows into the office space (for example, offering tickets to employees at artistic events); as a tool - when companies use art as a tool for management / leadership development (e.g. equipment, development of communication skills, etc.); and strategic transformation - when the business integrates the arts in areas such as vision and values, creativity and innovation, branding and marketing.

Some of the statistical methods used in the analysis of the influences manifested in a social context were Informational Energy and Informational Correlation Onicescu.

Academician Octav Onicescu (1892-1983), is one of the greatest mathematicians of Romania with a remarkable international reputation. Informational Energy Onicescu, according to the description given by Rizescu and Avram (2014), and Mihaiță (1983), comprises the amount of information generated by the diversity of a context. If we take in consideration a system $S$ characterized by the statuses $s 1, s 2, \ldots, s n$ having the corresponding weights $p 1, p 2, \ldots, p n$, where $\sum_{i=1} p i=1$, the Onicescu Information Energy of the $S$ system is calculated as the sum of the squares of the weights of the individual statuses: $E s=\sum n_{i=1} p i^{2}$ The information Energy values range from $1 / n$ to 1 . The Information Energy reaches the value $1 / n$ when all the statuses have the same probability $1 / n$ (the uniformity of the system achieved) and 1 when one of the statuses of the system has a weight of 1 (and therefore all the other 0 ). The informational energy decreases in direct proportion with the increase of uniformity, or determination of systems.

The basic concept of Onicescu information statistics is the Onicescu Informational Correlation. In order to describe the Onicescu Informational Correlation, the methodology presented by Mihaita and StanciuCapota (2005) or Oprea (2017) were used.

If we consider two experiments $A$ and $B$, characterized by a system with $n$ events: $A 1, A 2, \ldots, A n$ and $B 1$, $B 2, \ldots, B n$, with the following probability distributions: $p(A 1)=p 1, p(A 2)=p 2, \ldots, p(A n)=p n ; p(B 1)=q 1$, $p(B 2)=q 2, \ldots, p(B n)=q n$; the Onicescu Informational Correlation between $A$ and $B$, denoted IC $(A, B)$ can be calculated with the following formula: $I C(A, B)=\sum^{n_{i}=1} p_{i} q_{i}$

Informational correlation can take values between 0 and 1 and allows quantifying the association between two event systems having common characteristics. 


\section{OBJECTIVE AND METHODOLOGY OF RESEARCH}

This paper aims to evaluate the presence of art in the period of restrictions imposed by Covid-19, and the influences manifested by the presence of art on the lives of individuals and society.

The objectives of the paper include also the evaluation of the frequencies of consumption of different forms of art on different communication channels, on-line and off-line; the evaluation of the influences manifested by the presence of art and by the material comfort upon the feeling of life fulfilment; the influence of the presence of art upon the convictions regarding the capacity of art to consolidate the society.

Moreover, the paper evaluates the influences that are manifested in the arts world not only through the evaluation given by the respondents regarding these influences but goes further and analyzes the existence of influences that manifest themselves between the variables generated by the respondents' answers.

For this analysis, an experimental study was organized, during the first week of May 2020 on a sample of 200 people in the south of Romania. The data collection was organized using TalkOnlinePanel - company specialized in online interviews. The structure of the sample was defined using the next sampling rates:

- education: persons with university studies

- gender: $50 \%$ men and $50 \%$ women

- age: $35 \%$ of respondents with ages between 31 and 40 years old, $47 \%$ with ages between 41 and 50 years old and $18 \%$ others.

The sample included persons with higher education for assuring thus a consistent exposure of the respondents to art and therefore a more profound analysis of the impact of art in the life of individuals and in the life of society. The influence of education into the behavior of art consumer was also certified by the Cultural Barometer 2018 where it is confirmed that people with higher education have the greatest participation in cultural consumption (Croitoru and Becuț Mariescu, 2019).

In defining the questionnaire, different studies and statistical analyses carried out in recent years in the field of art ware taken into consideration, allowing the identification of the main factors which are manifesting in this field. Among the factors analyzed are the next ones: the presence of art in the lives of the respondents, the feeling of fulfilment in life, the material comfort and the convictions regarding the participation of the art in the life of individuals and in the consolidation the society.

The methods used in the research included the coefficient of association Yule and Onicescu Informational Correlation. Both indicators allow identifying the associations and the intensity of associations and were used in social analysis.

To determine the numerical value of the Yule coefficient of association, indicating the existence and intensity of the influence, next steps were defined. Using Microsoft Excel was constructed a table which 
include the contingency table for the variables generated by the two questions analyzed, plus a column with the Product of the two diagonals of the contingency table. On the line Total of this column, is included $\mathrm{R}=$ the ratio of the two Products. The Yule coefficient is calculated as

$Q=(R-1) /(R+1)$. An example of the computation for Yule Coefficient is presented in the table 1.

TABLE 1. YULE COEFFICIENT CALCULATION - ASSOCIATION BETWEEN PRESENCE OF ART AND THE SENTIMENT OF LIFE FULFILMENT

\begin{tabular}{|c|l|l|l|l|l|l|}
\hline \multicolumn{2}{|c|}{} & \multicolumn{3}{|l|}{ Cause (Presence of Art) } & \\
\cline { 2 - 7 } \multicolumn{2}{|c|}{} & $\begin{array}{l}\text { Partial Accord or } \\
\text { Disagreement }\end{array}$ & $\begin{array}{l}\text { Total } \\
\text { Accord }\end{array}$ & Total & $\begin{array}{l}\text { Diagonals' } \\
\text { product }\end{array}$ & $\begin{array}{l}\text { Yule } \\
\text { Coefficient }\end{array}$ \\
\hline $\begin{array}{c}\text { Effect } \\
\text { (Fulfilled } \\
\text { Life) }\end{array}$ & $\begin{array}{l}\text { Partial Accord or } \\
\text { Disagreement }\end{array}$ & 128 & 23 & 151 & 3968 & \\
\cline { 2 - 7 } & Total Accord & 18 & 31 & 49 & 414 & $81 \%$ \\
\cline { 2 - 7 } & Grand Total & 146 & 54 & 200 & 9.58 & \\
\hline
\end{tabular}

Source: Authors' own research

For evaluating the association

If: $Q=0$ lack of association between the two variables

$\mathrm{Q} \rightarrow 0$ weak association between the two variables

$Q \rightarrow \pm 1$ strong association between the two variables

$Q= \pm 1$ perfect association between the two variables

Yule coefficient in the table 1 shows that there is a strong association between the two variables.

Going further, Onicescu Informational Correlation Coefficient (noted Kcor) computation is presented.

To calculate this coefficient was used Microsoft Excel and a table was developed, starting from the table of contingency of the two variables and including two new columns. In the first new column is included the Informational Energy of those two alternatives, on the total line of this column is included the sum of the two informational energies - representing the Informational Energy of the system.

In the second column is calculated the sum of the squares of the weights of the two segments generated by the effect variable, applied in each of the two segments generated by the cause variable.

In the first line of the column is placed the square of the weights of the segments generated by the effect variable on the first segment generated by the cause variable, and in the second the square of the weights generated by the effect variable in the second segment generated by the cause variable. 
In the last line of the column (total line), is calculated the Onicescu Informational Correlation as a ratio between the Informational Energy and radically from the product of the two values in line 1 and line 2 of the same column.

TABLE 2. COEFFICIENT OF CORRELATION ONICESCU - ASSOCIATION OF THE PRESENCE OF ART AND THE FEELING OF LIFE FULFILMENT

\begin{tabular}{|c|l|l|l|l|l|l|}
\hline \multicolumn{2}{|c|}{} & \multicolumn{2}{|l|}{ Cause (Presence of Art) } & \\
\cline { 2 - 7 } & $\begin{array}{l}\text { Partial Accord } \\
\text { or } \\
\text { Disagreement }\end{array}$ & $\begin{array}{l}\text { Total } \\
\text { Accord }\end{array}$ & Total & $\begin{array}{l}\text { Informational } \\
\text { Energy }\end{array}$ & Kcor \\
\hline $\begin{array}{c}\text { Effect } \\
\text { (Fulfilled } \\
\text { Life) }\end{array}$ & $\begin{array}{l}\text { Partial Accord or } \\
\text { Disagreement }\end{array}$ & 128 & 23 & 151 & 0.37 & 0.78 \\
\cline { 2 - 8 } & Total Accord & 18 & 31 & 49 & 0.07 & 0.51 \\
\hline & Grand Total & 146 & 54 & 200 & 0.44 & 0.70 \\
\hline
\end{tabular}

Source: Authors' own research

Onicescu Informational Correlation Coefficient also indicates the presence of an association between the two analyzed variables.

The two computations presented above were used for analyzing different associations between the variables analyzed in the paper, the analyses of the results are presented further.

\section{RESULTS AND DISCUSSIONS}

One of the objectives of the study was to identify art consumption before and during the Covid-19 pandemic. For the evaluation of the art consumption, the results of the experimental study carried out in the first week of May 2020 were used.

Following the interview, it was observed that before the pandemic period, $21 \%$ of respondents went to the Cinema at least weekly, $37 \%$ went occasionally. Theater consumption was lower. $29 \%$ of respondents used to go to the theater at least monthly in the period before the pandemic. For the consumption of Literature in the period preceding the pandemic, the following frequencies were registered: $28 \%$ of the respondents read daily, $25 \%$ read weekly and $16 \%$ read monthly. Music consumption recorded some of the highest frequencies in the period before the pandemic, $64 \%$ of respondents listened to music daily.

To meet the need for art consumption during the pandemic, when cinemas, theaters or concert halls, as well as museums or exhibition halls were closed, art consumption has largely moved online. That is why for the Covid-19 pandemic period, the frequency of consumption was evaluated using the access solutions to the different forms of art manifestation. 
In the case of art consumption in accessible forms after the imposition of Covid-19 restrictions, the following consumption frequencies were recorded: $75 \%$ of respondents consume at least weekly movies on Internet platforms (Netfilix, HboGo, others); $34 \%$ of respondents consume weekly Theater on Internet platforms (online TV stations, plays broadcast online, others); $73 \%$ consume at least weekly Music on Online TV stations, websites specialized in broadcast music, others.

A brief image of art consumption during the Covid-19 period, according to the answers received is given in the table 3.

TABLE 3. CONSUM OF ART DURING COVID-19

\begin{tabular}{|c|c|c|c|c|c|}
\hline & Frequencies & Man & Woman & Grand Total & Share $(\%)$ \\
\hline \multirow{5}{*}{$\begin{array}{l}\text { Movies on } \\
\text { Internet } \\
\text { platforms } \\
\text { (Netflix, Hbo } \\
\text { Go, others) }\end{array}$} & Daily & 54 & 38 & 92 & $46 \%$ \\
\hline & Weekly & 25 & 33 & 58 & $29 \%$ \\
\hline & Monthly & 2 & 1 & 3 & $2 \%$ \\
\hline & Occasional & 8 & 8 & 16 & $8 \%$ \\
\hline & Not at all & 11 & 20 & 31 & $16 \%$ \\
\hline \multirow{5}{*}{$\begin{array}{c}\text { Theater on } \\
\text { Internet } \\
\text { Platform } \\
\text { (Online TV } \\
\text { Stations, } \\
\text { Online } \\
\text { Plays, } \\
\text { Others) }\end{array}$} & Daily & 13 & 4 & 17 & $9 \%$ \\
\hline & Weekly & 26 & 25 & 51 & $26 \%$ \\
\hline & Monthly & 8 & 11 & 19 & $10 \%$ \\
\hline & Occasional & 30 & 24 & 54 & $27 \%$ \\
\hline & Not at all & 23 & 36 & 59 & $30 \%$ \\
\hline \multirow{5}{*}{$\begin{array}{c}\text { Music on } \\
\text { Internet } \\
\text { platforms } \\
\text { (Online TV } \\
\text { stations, } \\
\text { Online plays, } \\
\text { others) }\end{array}$} & Daily & 59 & 54 & 113 & $57 \%$ \\
\hline & Weekly & 13 & 20 & 33 & $17 \%$ \\
\hline & Monthly & 5 & 6 & 11 & $6 \%$ \\
\hline & Occasional & 20 & 7 & 27 & $14 \%$ \\
\hline & Not at all & 3 & 13 & 16 & $8 \%$ \\
\hline \multirow{4}{*}{$\begin{array}{l}\text { Literature in } \\
\text { classic } \\
\text { format } \\
\text { (books) or }\end{array}$} & Daily & 31 & 36 & 67 & $34 \%$ \\
\hline & Weekly & 25 & 26 & 51 & $26 \%$ \\
\hline & Monthly & 13 & 12 & 25 & $13 \%$ \\
\hline & Occasional & 23 & 19 & 42 & $21 \%$ \\
\hline
\end{tabular}


Coman, I.

ART CONSUMPTION DURING COVID-19 PANDEMIC: INFLUENCE UPON THE SENTIMENT OF LIFE FULFILMENT

\begin{tabular}{|c|c|c|c|c|c|}
\hline electronic & Not at all & 8 & 7 & 15 & $8 \%$ \\
\hline \multirow{5}{*}{$\begin{array}{c}\text { Fine Arts - } \\
\text { through } \\
\text { online } \\
\text { platforms of } \\
\text { major } \\
\text { museums }\end{array}$} & Daily & 6 & 3 & 9 & $5 \%$ \\
\hline & Weekly & 8 & 9 & 17 & $9 \%$ \\
\hline & Monthly & 14 & 13 & 27 & $14 \%$ \\
\hline & Occasional & 32 & 34 & 66 & $33 \%$ \\
\hline & Not at all & 40 & 41 & 81 & $41 \%$ \\
\hline \multirow{6}{*}{ Other } & Daily & 3 & 4 & 7 & $4 \%$ \\
\hline & Weekly & 3 & 3 & 6 & $3 \%$ \\
\hline & Monthly & 1 & 2 & 3 & $2 \%$ \\
\hline & Occasional & 8 & 7 & 15 & $8 \%$ \\
\hline & Not at all & 41 & 43 & 84 & $42 \%$ \\
\hline & -- & 44 & 41 & 85 & $43 \%$ \\
\hline
\end{tabular}

Source: Authors' own research

A summary of the respondents' answers to the question: "Do you consider that art has influenced your life?" is presented in graphic number 2.

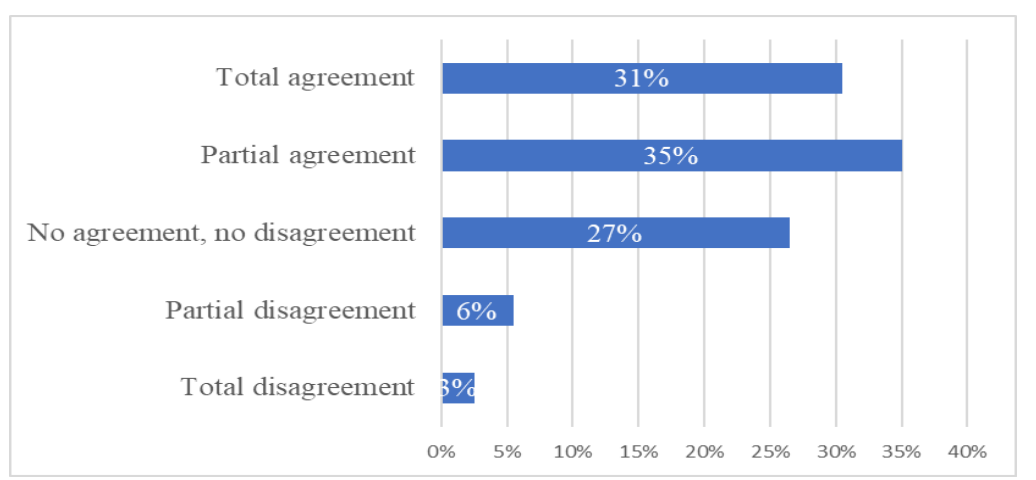

GRAPHIC 2. RESPONDENTS 'CONSIDERATIONS REGARDING THE INFLUENCE OF ART ON THEIR LIVES

Source: Authors' own research

Most of respondents $(67 \%)$ agree that art manifested influence upon their life. These answers create the expectation that the results of the research reveal the existence of an influence of the presence of art upon the feeling of life fulfilment.

\subsection{THE INFLUENCE OF THE PRESENCE OF ART UPON THE FEELING OF LIFE FULFILLMENT}

In order to evaluate the influence of the presence of art upon the sentiment of life fulfilment was analyzed the association between the answers received from the question regarding the presence of art and question regarding the sentiment of life fulfilment. The association between the two variables generate by 
these questions were analyzed using the coefficient of association Yule and Onicescu Informational Correlation.

Yule coefficient calculated for this association (0.81) shows that there is a strong association between the two variables. Onicescu Informational Correlation Coefficient (0.70) also indicates the presence of an association between the two analyzed variables. Both coefficients indicate that the presence of art manifests an influence upon the feeling of fulfilment in life.

For a deeper analysis, several control variables were used. These variables were applied to segment the population and evaluate how the associations manifest themselves within the segments.

The control variables used and the segments generated by their application are: Age, 44\% of respondents are less than 40 years old, and 56 are over 40 years old; Education, $71 \%$ of respondents have graduated higher education, and $29 \%$ of respondents have graduated post university education and Gender, $50 \%$ of respondents are women, and $50 \%$ are men.

Yule Coefficient for the association between Presence of Art - Feeling of Life fulfilment for persons with age less than 40 years was 0.88 , and Onicescu Correlation Coefficient was 0,75 . The results by the two coefficients in the case of people less than 40 years old are similar, both revealed there is an association.

A synthesis of the values calculated for Yule Coefficient and Onicescu Informational Correlation is presented in table 4.

TABLE 4. ONICESCU INFORMATIONAL CORRELATION AND YULE COEFFICIENT CALCULATED FOR ASSOCIATION BETWEEN PRESENCE OF ART AND SENTIMENT OF LIFE FULFILMENT

\begin{tabular}{|l|r|r|}
\hline Cause (Presence of Art)/ Effect (Fulfilled Life) & $\begin{array}{l}\text { Onicescu } \\
\text { Informational } \\
\text { Correlation }\end{array}$ & Yule Coefficient \\
\hline Total & 0.78 & 0.81 \\
\hline$<40$ years old & 0.75 & 0.88 \\
\hline$>40$ years old & 0.68 & 0.77 \\
\hline Postgraduate studies & 0.52 & 0.86 \\
\hline University studies & 0.8 & 0.78 \\
\hline Men & 0.71 & 0.79 \\
\hline Women & 0.69 & 0.78 \\
\hline
\end{tabular}

Source: Authors' own research

In the case of people over the age of 40 , the results of both coefficients reveal a stronger association, so we can say that for people over the age of 40 art had a stronger influence on the feeling of fulfillment in life compared to the same association calculated for the whole sample. 
The analysis is continued for the evaluation of the influences that manifest depending on the education.

Evaluating the Association between Presence of Art and the Sentiment of Life fulfilment for persons with university studies the analysis reveals the existence of an association similar to the one at the level of the whole sample. The association between Presence of Art - Sentiment of Life fulfilment for persons with postgraduate studies evaluated by both Yule coefficient and Onicescu Informational Correlation reveal a stronger association comparing to the association manifested for the whole sample.

The evaluation applied in the segment generated by gender demonstrate that the association between the presence of art in the life of respondents and the sentiment of life fulfilment is similar in the case of men comparing to the whole sample. In the case of women, a stronger association is present between the two variables: presence of art and life fulfilment sentiment.

As a result of the analyze carried out, it is highlighted that the presence of art manifests the influence on the feeling of fulfillment in life.

The influence of the presence of art on the sentiment of fulfillment in life is found in all the segments generated by the selected control variables and in some of the segments a stronger association is highlighted. Thus, in the case of people over 40 years of age, as well as people with postgraduate studies and women, there were stronger associations between the presence of art and the feeling of fulfillment in life compared to the associations that manifest at the level of the entire sample.

These differences between the intensity of the associations were quantified in the case of both statistical methods used: Yule Coefficient and the Onicescu Correlation Coefficient.

\subsection{THE INFLUENCE OF THE MATERIAL COMFORT UPON THE FEELING OF LIFE FULFILLMENT}

The statistical methods described above were applied for analyzing the association between material comfort and the feeling of life fulfilment. The Results are presented in table 5.

TABLE 5. ONICESCU INFROMATIONAL CORRELATION AND YULE COEFFICIENT CALCULATED FOR ASSOCIATION BETWEEN MATERIAL COMFORT AND SENTIMENT OF LIFE FULFILMENT

\begin{tabular}{|l|l|r|}
\hline Cause (Material Comfort)/ Effect (Fulfilled Life) & $\begin{array}{l}\text { Onicescu } \\
\text { Informational } \\
\text { Correlation }\end{array}$ & \multicolumn{2}{l|}{ Yule Coefficient } \\
\hline Total & 0.66 & 0.91 \\
\hline$<40$ years old & 0.62 & 0.97 \\
\hline$>40$ years old & 0.69 & 0.86 \\
\hline Postgraduate studies & 0.39 & 0.97 \\
\hline University studies & 0.72 & 0.89 \\
\hline Men & 0.67 & 0.88 \\
\hline Women & 0.64 & 0.95 \\
\hline
\end{tabular}

Source: Authors' own research 
For the association between Material Comfort and sentiment of Life fulfilment both coefficients indicate that we have a strong association. The association between material comfort and the feeling of fulfilment in life is stronger than the association between the presence of art and the feeling of fulfilment in life.

Analysing the values registered by the two coefficients, it was observed that the material comfort has a greater influence on the feeling of fulfilment in life in the case of people under 40 years old. If the influence of the presence of art on the feeling of fulfilment in life is less pronounced in the case of people over the age of 40 , the material comfort has a greater impact among younger people.

Among those with postgraduate studies, there was also assessed a stronger association between the feeling of fulfillment in life and material comfort. In the same segment, the influence of the presence of art was also stronger comparing with the association manifested for the segment of respondents with university studies.

Women are another segment where material comfort has had a strong influence on the feeling of fulfillment in life, compared to men. There was also a stronger influence of the presence of art among women compared to men.

\subsection{THE INFLUENCE OF THE PRESENCE OF ART UPON THE CONVICTIONS REGARDING THE CAPACITY OF ART TO CONSOLIDATE THE SOCIETY}

The statistical methods presented were also used for assessment of the association existing between the Presence of Art and the conviction regarding the capacity of art to participate to the consolidation of the society. The Yule coefficients and the Onicescu Informational Correlation calculated for the whole sample and for segments obtained by using the control variables are presented in table 6 .

TABLE 6. ONICESCU INFROMATIONAL CORRELATION AND YULE COEFFICIENT CALCULATED FOR ASSOCIATION BETWEEN PRESENCE OF ART - CAPACITY OF ART TO CONSOLIDATE SOCIETY

\begin{tabular}{|l|l|r|}
\hline $\begin{array}{l}\text { Cause (Presence of Art)/ Effect } \\
\text { (Consolidation of society) }\end{array}$ & $\begin{array}{l}\text { Onicescu } \\
\text { Informational } \\
\text { Correlation }\end{array}$ & Yule Coefficient \\
\hline Total & 0.6 & 0.82 \\
\hline$<40$ years old & 0.6 & 0.82 \\
\hline$>40$ years old & 0.92 & 0.42 \\
\hline Postgraduate studies & 0.62 & 0.78 \\
\hline University studies & 0.6 & 0.84 \\
\hline Men & 0.55 & 0.86 \\
\hline Women & 0.65 & 0.77 \\
\hline
\end{tabular}

Source: Authors' own research 
For the association between Presence of art and Convictions regarding the capacity of art to consolidate society both coefficients indicate that we have an association.

Moreover, comparing this association with the other associations analysed it was revealed that both coefficients indicate we have an association, but this association is weaker compared to the associations between material comfort and the feeling of fulfilment in life and the association between the presence of art and the feeling of fulfilment in life.

Comparing the influence of the presence upon the convictions regarding the capacity of art to consolidate society into the segments generated by the age of the respondents, it was observed that in the case of people under 40 years old the association is stronger compared to the association evaluated in the case of people over 40 years old. Also, in the case of people with university studies, the association is stronger compared to the same association manifested in the case of respondents with postgraduate studies. When it was used gender as variable of control, the association was stronger in the segment of men comparing to the segment of women.

\section{CONCLUSIONS}

Although at an intuitive level is considered that art has an influence on each one of us, or on society, in this paper these influences of art are analyzed using statistical methodologies.

Art is present in the life of respondents, only $4.5 \%$ of respondents expressed their disagreement (total or partial) regarding the presence of art in their life.

$46 \%$ of respondents consume daily movies on Internet platforms (Netfilix, Hbo Go, others) and $29 \%$ of them weekly; $9 \%$ of respondents consume daily Theatre on Internet platforms (online TV stations, plays broadcast online, others) and $26 \%$ of them weekly; $57 \%$ consume at daily Music on Online TV stations, music streaming websites, others and $17 \%$ of them weekly.

Most of respondents $(66 \%)$ consider that art influences the life of respondents (total or partial agreement). The analysis carried out went more in depth and confirmed that Presence of Art manifests an influence upon the sentiment of Life Fulfilment.

$89.5 \%$ of the respondents consider that art participates to the consolidation of the community and of the society. Also, the presence of art manifests an influence upon the convictions regarding the capacity of art to participate to the consolidation of the community, which is another conclusion of the analysis carried out. Moreover, the influence of art upon the convictions regarding the consolidation of society has proved to be weaker if is compared with the influence of presence of art upon the feeling of life fulfilment. 
The research reveals also that for persons with post university studies presence of art and material comfort have stronger influences upon the feeling of life fulfilment comparing to the same influences manifested for respondents with university studies. Also, for persons with post university studies the convictions regarding the capacity of art to participate to the consolidation of community is less influenced by the presence of art. In the case of women the feeling of life fulfilment is higher influenced by the presence of art comparing with men, and for men presence of art influence in higher degree the convictions regarding the capacity of art to participate to the consolidation of society comparing with the influence manifested in the case of women.

For persons with age less than 40 years old the study revealed that the material comfort influence upon life satisfaction is stronger comparing with the same influence manifested for respondents with age over 40 years. Also, for persons with age less than 40 years old the presence of art influence in higher degree the convictions regarding the capacity of art to participate to the consolidation of society comparing to the same influence manifested for respondents with age over 40 years old.

With the multitude of dynamics and influences, art has been and continues to be a part of our lives. Art participates in building the sentiment of life fulfillment and continues to participate to the consolidation of the community and the society.

\section{REFERENCES}

Bachled, C. L., Asmae, B. (2016). Personality and interest in the visual arts. Arts and the Market. 6(2): $126-140$

Chung, J. B., Yun, G. W., (2013). Media and social amplification of risk: BSE and H1N1 cases in South Korea. Disaster Prevention and Management. 22(2): 148 -159

Coman, I., Mihaita, N. (2019). Factors influencing the impact of Art on the life satisfaction. 8th INTERNATIONAL CONFERENCE SYNERGIES in COMMUNICATION. 39-49

Croitoru, C., Becuț Marinescu A. (2017). Barometrul de Consum Cultural 2016: 0 radiografie a practicilor de consum cultural. Bucharest: Universul academic

Croitoru, C., Becuț Marinescu A. (2019), Barometrul de Consum Cultural 2018: Dinamica sectorului cultural în anul Marii Unin. Bucharest: Universul academic

De Arriba, R., Girardi, G,. Vidagañ, M. (2019). Contemporary art in higher education: Creative pedagogies in political economy. Thinking Skills and Creativity 33(2019): 1-9

Gabeaud, A. (1930). Histoire de la Musique. Paris: Librairie Larousse

Gombrich, E. H. (2012). Istoria Artei. Translation Nicolae Constantinescu, Bucharest: Art

Jeon, M. Fiebrink, R., Edmonds, E. A., Herath, D. (2019) From rituals to magic: Interactive art and HC lof the past, present, and future. International Journal of Human-Computer Studies 131(2019): 108 119

Korstanje, M., Babu, G. (2016). Media constructions of fear in the outbreak of an epidemic disease: The case of dengue fever in Argentina. International Journal of Emergency Services. 5(1): 95-104 
Li, Y., Zhao, H. V., Chen, Y. (2019). An epidemic model for correlated information diffusion in crowd intelligence networks. International Journal of Crowd Science. 3(2): 168-183

Mihaita, N., Stanciu-Capota, R. (2005). Relations statistiques fortes, cachees, fausses, et illusories Applications de la statistique informationelle. Bucharest: ASE

Muhammad, F. J., Hanita, N., Mohamab, N. (2016). Roles of Public Art in Malaysian Urban Landscape towards Improving Quality of Life: Between aesthetic and functional value. Procedia - Social and Behavioral Sciences. 222(2016): $872-880$

Nissley, N. (2010). Arts-based learning at work: economic downturns, innovation upturns, and the eminent practicality of arts in business. Journal of Business Strategy. 31(4): 8-20

Oprea, M. (2017). An Overview on the Contributions of the Academician Octav Onicescu to the Informational Statistics and Further Developments. The $12^{\text {th }}$ International Conference on Virtual Learning VIRTUAL LEARNING - VIRTUAL REALITY. 54-63.

Otte, H. (2019). Bonding or bridging? On art participation and social cohesion in a rural region of the Netherlands. Poetics 76 (2019): 1-14

Pantano, E. (2011). Cultural factors affecting consumer behavior: a new perception model. Euromed journal of business. 6(1): 117-136

Rodner, V. L., Maktoba, O., Thomson, E. (2011). The brand-wagon: emerging art markets and the Venice Biennale. Marketing Intelligence and Planning. 29(3): 319 - 336

Rizescu, D., Avram, A. (2014) Using Onicescu's Informational Energy to Approximate Social Entropy, Procedia - Social and Behavioral Sciences, 114(2014): 377-381 